\title{
A new Centromerus Dahl, 1886 (Aranei: Linyphiidae: Micronetinae) from South of the Russian Plain
}

\author{
Новый вид рода Centromerus Dahl, 1886 (Aranei: Linyphiidae: \\ Micronetinae) с юга Русской равнины
}

\author{
Valery A. Gnelitsa ${ }^{1}$ \& Alexander V. Ponomarev ${ }^{2}$ \\ В.А. Гнелиџа ${ }^{1}$, А.В. Пономарев ${ }^{2}$
}

\begin{abstract}
${ }^{1}$ Sumy State Teacher's Training University, Romenskaja Str. 87, Sumy 40002, Ukraine, E-mail: Gnelitsa@mail.ru Сумской государственный педуниверситет им. А.С. Макаренко, ул. Роменская 87, Сумы 40002 Украина.

${ }^{2}$ Southern Scientific Centre of RAS, Chekhov Str., 41, Rostov-on-Don 344006 Russia, E-mail: ponomarev1952@mail.ru Южный научный центр РАН, пр. Чехова, 41, Ростов-на-Дону 344006 Россия.
\end{abstract}

KEY WORDS: Aranei, Linyphiidae, Centromerus, new species, Russian Plain, steppe.

КЛЮЧЕВЫЕ СЛОВА: Aranei, Linyphiidae, Centromerus, Linyphiidae, новый вид, Русская Равнина, степь.

ABSTRACT. Centromerus pratensis sp.n., is described from the southern part of the Russian Plain, and seems to be the smallest known representative of the genus Centromerus Dahl, 1886. The species is most similar to C. piccolo Weiss, 1996 and C. andriescui Weiss, 1987, but differs by the smaller size and by the details of genitalia in both sexes.

РЕЗЮМЕ. Новый вид Centromerus pratensis sp.n. описан с юга Русской равнины и является самым мелким известным представителем рода Centromerus Dahl, 1886. Вид наиболее близок к C. piccolo Weiss, 1996 и C. andriescui Weiss, 1987 и отличается меньшими размерами и деталями строения гениталий обоих полов.

\section{Introduction}

Centromerus is a large Holarctic genus which contains 87 species [Platnick, 2010] with Micryphantes aequilis C.L. Koch, 1841 as the type species. The list of the former Soviet Union includes 28 Centromerus species [Mikhailov, 1997, 1998, 1999, 2000]. Eight species are registered in the southern part of the Russian Plain, and five of them (C. abditus Gnelitsa, 2007; C. brevivulvatus Dahl, 1912; C. capucinus (Simon, 1884); C. sellarius (Simon, 1884) and Centromerus sylvaticus (Blackwall, 1841)) are reported the Rostov region.

Recent collecting in the Rostov region (southern part of the Russian Plain, Russia) has revealed a new species, Centromerus pratensis sp.n., which is here described.

\section{Material and Methods}

This paper is based on the spider material collected by A.V. Ponomarev and V.L. Perepechayenko from
Rostov Area, Russia, in 2004-2009. The holotype is deposited in the collection of the Zoological Museum of Moscow State University (ZMMU). Paratypes are in V.A. Gnelitsa's personal collection (GPC) and A.V. Ponomarev's personal collection (PPC).

Abbreviations for the names of the separate structures of the palp and the epigyne were adopted from Merrett [1963] with some changes according Millidge [1977], Saaristo \& Tanasevitch [1996], Hormiga, [2000]: AP — anteroproximal part of the median membrane; ARP - anterior radical process; C - cymbium; DSA - distal suprategular apophysis; EAPP edge of the general anterior - posterior pockets of paracymbium; EP - embolus proper; FG - Fickert's gland; LPR - lamellar part of radix (the place of the lamella characteristica connecting; here lamella characteristica reduced completely); MM - median membrane; Pc — paracymbium; PT — palpal tibia; R radix; SPT — suprategulum; $\mathrm{St}$ - subtegulum; Str stretcher; T - tegulum; TA - terminal apophysis. All measurements are in $\mathrm{mm}$.

\section{Centromerus pratensis sp.n.}

Fig. 1.

MATERIAL. Holotype: $0^{7}$ (ZMMU), Russia, Rostov Region, Ust-Donetsk Distr., Razdorskaya Stanitsa (N 47 $31^{\prime}$, E $40^{\circ} 38^{\prime}$ ), "Krasny Yar" locality, dry meadow, 28.04-02.05.2003, A.V. Ponomarev. Paratypes: + (GPC) Russia, Rostov Region, Ust-Donetsk Distr., Razdorskaya Stanitsa, near the house, 04.03.2003; of 18.04.2005, same place; $+\sigma^{7}$ (GPC) "Puchlyakov" slopes of the Don River, sandy riverside with Xanthium, 23.03.2004, A.V. Ponomarev; $O^{7}$ (PPC) Orlovsky Distr., Manych Settlement, grass-Artemisia steppe, 14-18.04.2009, V.L. Perepechayenko.

DIAGNOSIS. The new species is characterized by the very small body size in both sexes and by the peculiarities of the genitalic structures. For more detail comparison with congeners see "Taxonomic Remarks". 

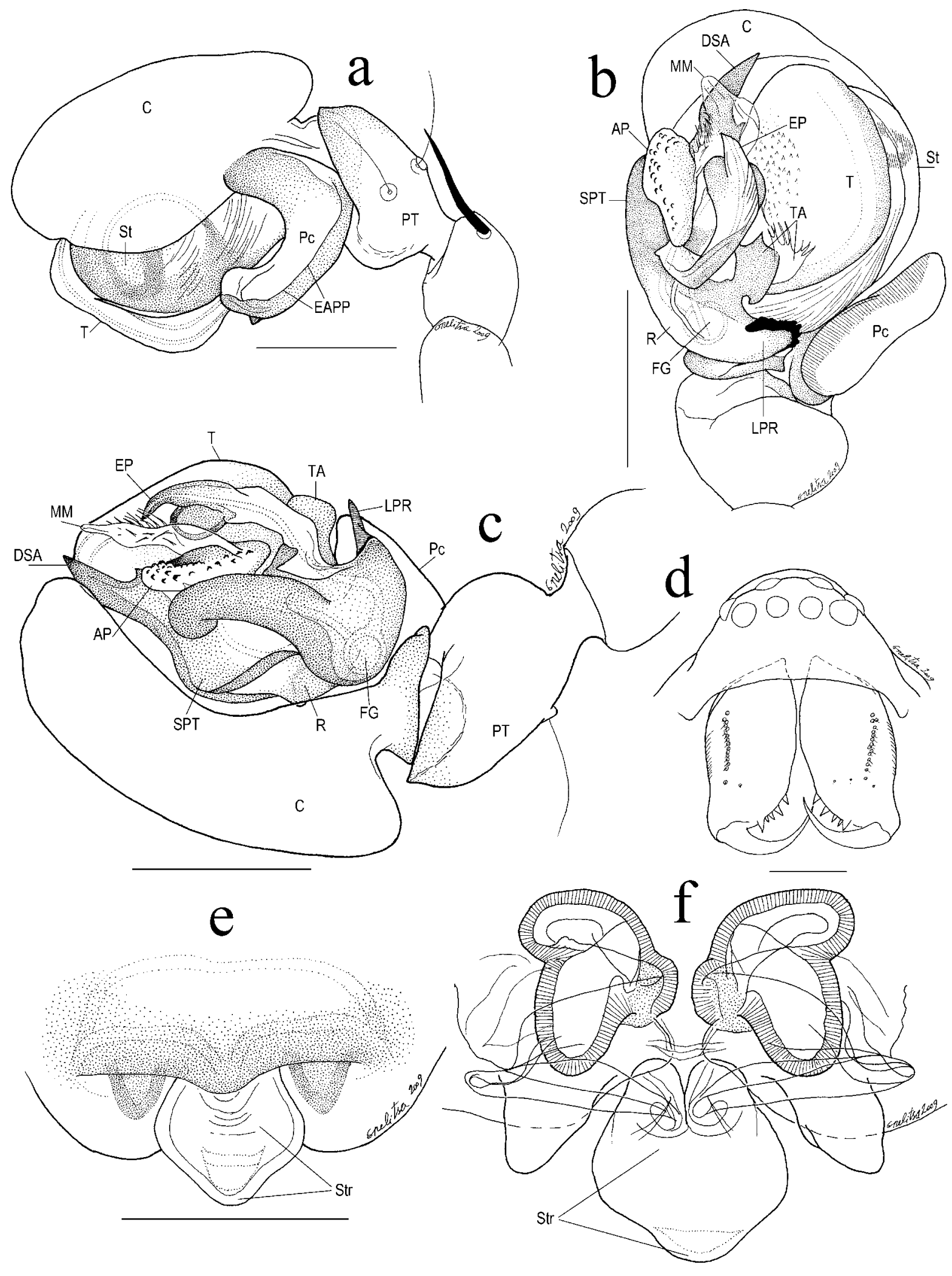

Fig. 1. Centromerus pratensis sp.n.: a-c - male palp, lateral, ventral and median views; $\mathrm{d}$ - male prosoma, frontal view; e epigyne ventral view; $\mathrm{f}$ - vulva. Scale: $0.1 \mathrm{~mm}$.

Рис. 1. Centromerus pratensis sp.n.: a-c - пальпа самца, вид сбоку, вентрально и медиально; $\mathrm{d}$ - головогрудь самца, вид спереди; е - эпигина, вид снизу; $\mathrm{f}$ - вульва. Масштаб: 0,1 мм. 
DESCRIPTION. Male. Total length 0.97. Carapace 0.59 long, 0.45 wide, yellow-grey. Sternum 0.34 long and 0.34 wide, yellow-grey. Posterior median eyes separated by $4 / 5$ of their diameter. Promargins of chelicerae with one tooth near the base of the fang, retromargins with 4 teeth, frontal surface with small spines stand in vertical row (Fig. 1d), stridulating files barely visible. Legs yellow, tibia bear only two spines (dorsally); position of metatarsal trichobothrium: I -0.40 , II -0.39 , III -0.38 . Length of leg segments:

\begin{tabular}{|l|c|c|c|c|c|}
\hline Leg & Femur & Patella & Tibia & Metatarsus & Tarsus \\
\hline I & 0.43 & 0.16 & 0.40 & 0.35 & 0.28 \\
\hline II & 0.38 & 0.16 & 0.32 & 0.31 & 0.27 \\
\hline III & 0.35 & 0.15 & 0.27 & 0.27 & 0.24 \\
\hline IV & 0.46 & 0.15 & 0.45 & - & - \\
\hline
\end{tabular}

Palp as in Figs 1a-c. Cymbium humped dorsally and proximally directed; edge of general anterior posterior pockets of paracymbium (EAPP) toothless; terminal apophysis of radix with two branches: sclerotized one and membrane part frontal-laterally joined to it; lamellar part of the radix flat with wavy edge, bearing no appendages; anteroproximal part of the median membrane tuberculated; median membrane broad and somewhat curved in its distal third; palpal tibia with two trichobothria.

Abdomen uniformly dark grey.

Female. Total length 0.71. Carapace 0.56 long, 0.42 wide, yellow-grey with large grey patch centrally. Sternum 0.34 long, 0.32 wide, yellow-grey with slightly darker margins. Posterior median eyes a diameter of one apart. Promargins of chelicerae with 3 teeth, retromargins with 4 tiny teeth close together. Legs yellow; chaetotaxy as in male. Position of metatarsal trichobothrium: I -0.37 , II -0.37 , III -0.34 . Length of leg segments:

\begin{tabular}{|l|c|c|c|c|c|}
\hline Leg & Femur & Patella & Tibia & Metatarsus & Tarsus \\
\hline I & 0.40 & 0.15 & 0.34 & 0.29 & 0.24 \\
\hline II & 0.35 & 0.14 & 0.28 & 0.27 & 0.22 \\
\hline III & 0.31 & 0.13 & 0.24 & 0.24 & 0.21 \\
\hline IV & 0.42 & 0.15 & 0.40 & 0.34 & 0.22 \\
\hline
\end{tabular}

Epigyne and vulva as in Figs 1e,f. Epigyne as shown in Fig. 1e: scapus totally reduced, stretcher large, rhomboid-shaped.

Abdomen uniformly dark grey.

TAXONOMIC REMARKS. The male of Centromerus pratensis sp.n. may be confused with that of C. cinctus (Simon, 1884), C. cottarellii Brignoli, 1979, C. minutissimus Merrett et Powell, 1993, C. piccolo Weiss, 1996, C. subcaecus Kulczyński, 1914 and $C$. succinus (Simon, 1884). The main differences of these species from the new one are listed below.

In $C$. cottarellii the chaetotaxy is $1: 1: 1: 1$ instead 2:2:2:2 in C. pratensis sp.n.
In $C$. cinctus the distal suprategular apophysis is more narrow; the terminal apophysis differs in shape; basal chitinized sclerite (triangle-shaped) smaller than its distal membranous part. Distal branch of paracymbium round-triangular, not round-rectangular as in $C$. pratensis sp.n.

In $C$. minutissimus the suprategulum with a large slightly curved tooth-like outgrowth ventrally, instead in C. pratensis sp.n. it is absent.

In $C$. piccolo paracymbium with a ventral outgrowth on the distal branch (Fig. 2a); terminal apophysis with a narrow distal membrane (Fig. 2c); Fickert's gland in the middle of the anterior radical process, not near the base of the embolus (Fig. 2b); median membrane tapering, not rounded as in C. pratensis sp.n. (cf. Figs $2 \mathrm{~b}$ $\& 2 \mathrm{c})$.

In C. subcaecus terminal apophysis elongated; embolus proper much longer and wider; median membrane sharply curved; distal suprategular apophysis with robust additional tooth.

In C. succinus distal branch of the paracymbium round-triangular; in $C$. pratensis sp.n. round-rectangular; distal suprategular apophysis with a long and narrow additional tooth; terminal apophysis narrow with almost reduced membranous part.

The female of the new species differs from the similar C. andriescui Weiss, 1987, from Romania (male is unknown) by having the epigyne with a wide roundrhombic scapus (elongated-oval in C. pratensis sp.n.); vulva with relatively wide and shortened receptacles; vulva without any wide horn-like parts pointed at the tip; ducts inside directed frontal-laterally outside the receptacles Figs 2d,e.

ACKNOWLEDGEMENTS. Authors are very much obliged to Drs A. Tanasevitch and Yu. Marusik for their kind help in improving of the manuscript text.

\section{References}

Hormiga G. 2000. Higher level phylogenetics of erigonine spiders (Araneae, Linyphiidae, Erigoninae) // Smithsonian Contributions to Zoology. Vol. 609. P.1-160.

Merrett P. 1963. The palpus of male spiders of the family Linyphiidae // Proc. zool. Soc. Lond. Vol.140. P.347-467.

Millidge A.F. 1977. The conformation of the male palpal organs of linyphiid spiders, and its application to the taxonomic and phylogenetic analysis of the family (Araneae: Linyphiidae) // Bull. Br. arachnol. Soc. Vol.4. Pt.1. P.1-60.

Mikhailov K.G. 1997. Catalogue of the spiders of the territories of the former Soviet Union (Arachnida, Aranei) // Sbornik trudov Zoologicheskogo Museya MGU. Vol.37. 416 p.

Mikhailov K.G. 1998. Catalogue of the spiders (Arachnida, Aranei) of the territories of the former Soviet Union. Addendum 1. Moscow: KMK Scientific Press Ltd. 50 p.

Mikhailov K.G. 1999. Catalogue of the spiders (Arachnida, Aranei) of the territories of the former Soviet Union. Addendum 2. Moscow: Zoological Museum, Moscow State University. 39 p.

Mikhailov K.G. 2000. Catalogue of the spiders (Arachnida, Aranei) of the territories of the former Soviet Union. Addendum 3. Moscow: Zoological Museum, Moscow State University. 33 p.

Platnick N. 2010. The world spider catalog, version 11. American Museum of Natural History. http://research.amnh.org/entomology/spiders/catalog/index.html 

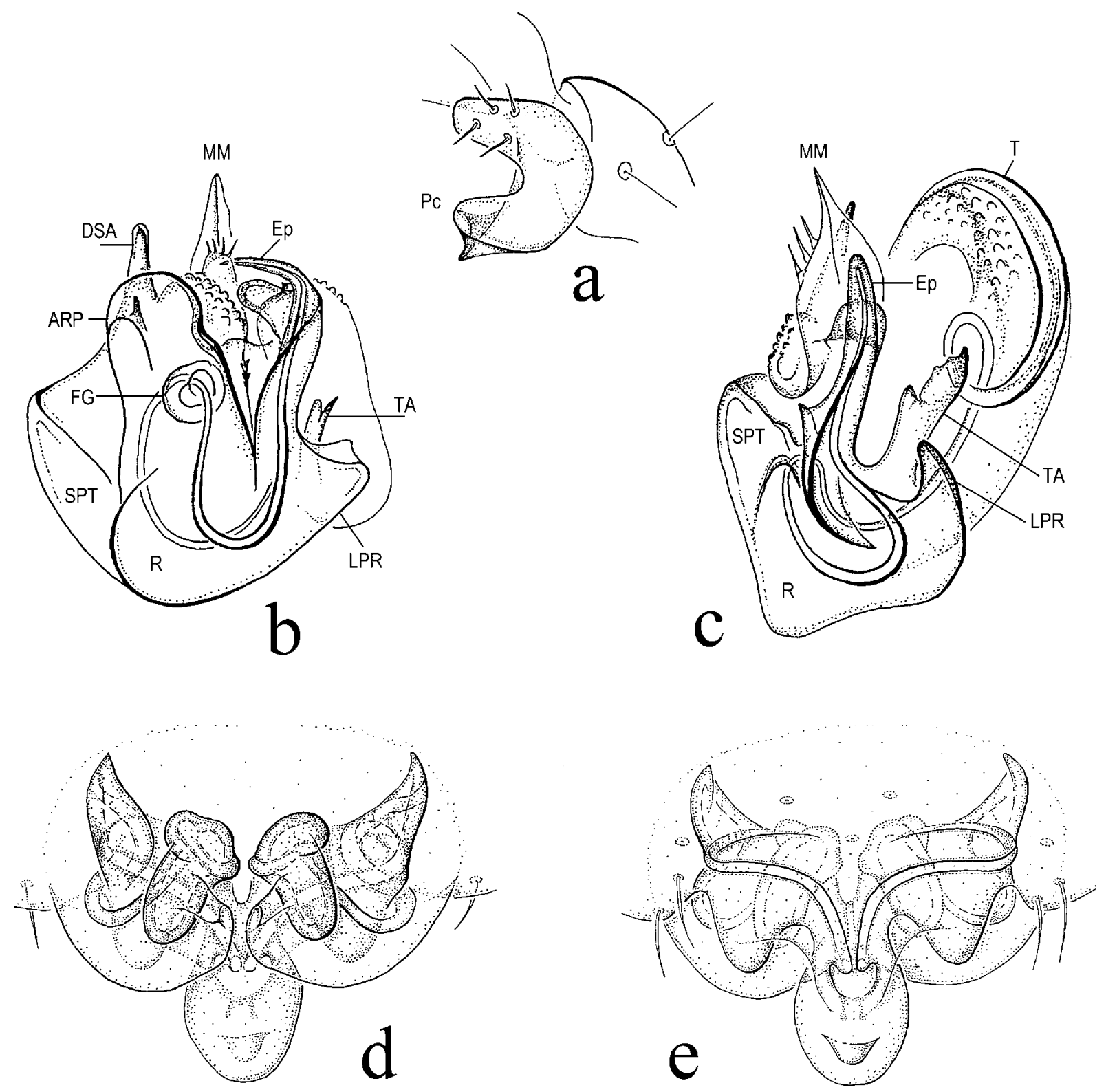

Fig. 2. Centromerus piccolo Weiss, 1996: a - paracymbium, b-c - male palp ventral and lateral-ventral views (after Weiss, 1996); C. andriescui Weiss, 1987: d-e - epigyne-vulva dorsal and ventral views (after Weiss, 1987). Scale: $0.1 \mathrm{~mm}$.

Pис. 2. Centromerus piccolo Weiss, 1996: a - парацимбиум, b-c - пальпа самца, вид снизу и снизу-сбоку (по Weiss, 1996); $C$. andriescui Weiss, 1987: d-e - эпигина-вульва, вид сверху и снизу (по Weiss, 1987). Масштаб: 0,1 мм.

Saaristo M.I., Tanasevitch A.V. 1996. Redelimitation of the subfamily Micronetinae Hull, 1920 and the genus Lepthyphantes Menge, 1866 with descriptions of some new genera (Aranei,
Linyphiidae) // Ber. Nat.-med. Verein Innsbruck Vol.83. P.163186.

Responsible editor Yu. Marusik 